\title{
The Subsoil Characterization of Matarbari Ultra Super Critical Coal-Fired Power Project, Bangladesh
}

\author{
Md. Shakil Mahabub ${ }^{1}$, Mohammad Rafikul Islam ${ }^{2}$ \\ ${ }^{1}$ Department of Geological Sciences, Jahangirnagar University, Dhaka, Bangladesh \\ ${ }^{2}$ Department of Civil Engineering, Dhaka University of Engineering and Technology, Dhaka, Bangladesh
}

\begin{abstract}
In this research, the subsoil characteristics and geotechnical issues have been evaluated for ground improvement, land development and design facilitation of Matarbari Ultra Super Critical Coal-Fired Power Project, Bangladesh. The subsoil conditions and geotechnical issues are addressed by determining the geotechnical parameters of soil. The soil characteristics are obtained from soil investigation and executed under land development for the procurement of power plant facilities. The American Society for Testing and Materials (ASTM International) standard is used to estimate all the soil parameters in field and laboratory tests. The measured soil properties establish the area consists mainly of two types of soils, i.e., Cohesive Clayey and non-cohesive Sandy soils. The cohesive soils are mostly composed of gray to dark gray CLAY, CLAY with Sand, SILT with Sand, and Sandy CLAY with fine to mediumgrained Sand. The upper cohesive soil layer (Ac-1) is very soft to soft, normal to slightly consolidated with low undrained cohesion. This layer is expected to have a high potential for differential settlement because of the proposed design load. The lower cohesive soils (Ac-2 and Ac-3) are firm to very stiff and moderately over consolidated. These soils have moderate to high shear strengths with low compressibility relating to the expected range of the design loads. The non-cohesive Sandy soils consist of dark gray to gray SAND, SAND with Silt, Silty SAND, and Clayey SAND. The Sandy soils are poorly graded and loose to very loose at the upper part (As-1) and medium dense to dense in lower parts (As-2 \& As-3) that expect less immediate settlement when a load placed on that. Geotechnical site conditions are challenging and deplorable. The soft soil layer Ac-1 (with As-1) complicates the design, especially in terms of foundation soil instability and settlement for certain structure types. Ground improvement techniques such as prefabricated vertical drain (PVD) and deep mixing method (DMM) can be applied to mitigate these challenges and for the improvement of the soft ground of the project area.
\end{abstract}

Keywords:- Soft Soils, Soil Properties, SPT, CPT, Shear Strength, Consolidation, Settlement, Ground Improvement.

\section{INTRODUCTION}

Bangladesh is a densely populated country and the consumption of energy per capita is insufficient for living minimum standards. Electricity serves as the primary source of power for most of the economic activities. The economy of Bangladesh does not flourish because of a shortage of electric power in various sector. The government of Bangladesh focused on eliminating the lack of electric power. For these reasons, the government of Bangladesh decided to establish a Power-Hub at Maheshkhali Island, Coxsbazar. Matarbari Ultra-Super Critical (USC) Coal-Fired Power Project is the first and one of the major development projects planned to implement at Matarbari Island of Maheshkhali Upzilla in Coxsbazar district.

The ground condition is unknown because of insufficient data or lack of research, and a detailed geotechnical investigation is essential to explore the project site. Therefore, this research addresses the soil characteristics, geotechnical challenges and mitigation measures for ground improvement and land development of the power plant area. The primary purposes of soil investigation are to provide the detailed geotechnical conditions for the subsoil improvement for the construction of the Power Plant with including the Coal Storage Yard, Roads, Embankment, Retaining wall, L-wall, Seawall, and Apron construction facilities.

The soil investigation has been conducted for characterizing the geotechnical problems and challenges of this site. Therefore, Sixty-four Cone Penetration Test (CPT) and Thirty-five land boreholes drilled for collecting in situ soil information. Standard penetration tests (SPT) has performed at each borehole and collection of disturbed and undisturbed soil samples for laboratory tests. Laboratory tests executed to obtain physical, index and mechanical properties of soils. The CPT's is conducted for collecting continues subsoil information through the selected depth without interruption. Geotechnical interpretation and evaluation are conducted from field and laboratory test results. Also, the challenges and mitigation measures are identified based on the factual interpretation of soil investigation data. Finally, geotechnical recommendations are suggested concerning the ground improvement and land development for the ground improvement, design and construction of the proposed engineering structure at the power plant and coal storage area. 
ISSN No:-2456-2165

\section{LOCATION AND GENERAL GEOLOGY OF THE PROJECT AREA}

The study area is located in the southeastern part of Bangladesh, about $60 \mathrm{~km}$ away in the south from Chittagong airport, shown in Fig. 1. The project site is situated in the southern coastal area of Matarbari-Dhalgata Island, which extends $14 \mathrm{~km}$ north-south and $4 \mathrm{~km}$ east-west at maximum. The coordinate of the project area within the latitude $21^{\circ} 40^{\prime} \mathrm{N}$ to $21^{\circ} 45^{\prime} \mathrm{N}$ and longitude $91^{\circ} 50^{\prime} \mathrm{E}$ to $91^{\circ} 55^{\prime} \mathrm{E}$. A meandering river is known as Kohelia between Matarbari-Dhalgata Island and Moheskahli Island. Many large swamps developed behind the beach around the site used for salt fields and shrimp ponds, which may have been mangrove swamps. The quick changes in beach shape are observed on the sea at the site because of the strong tidal current. The location of the boreholes and Pre-cone Penetration Tests (PCPT) is shown in Fig. 1.

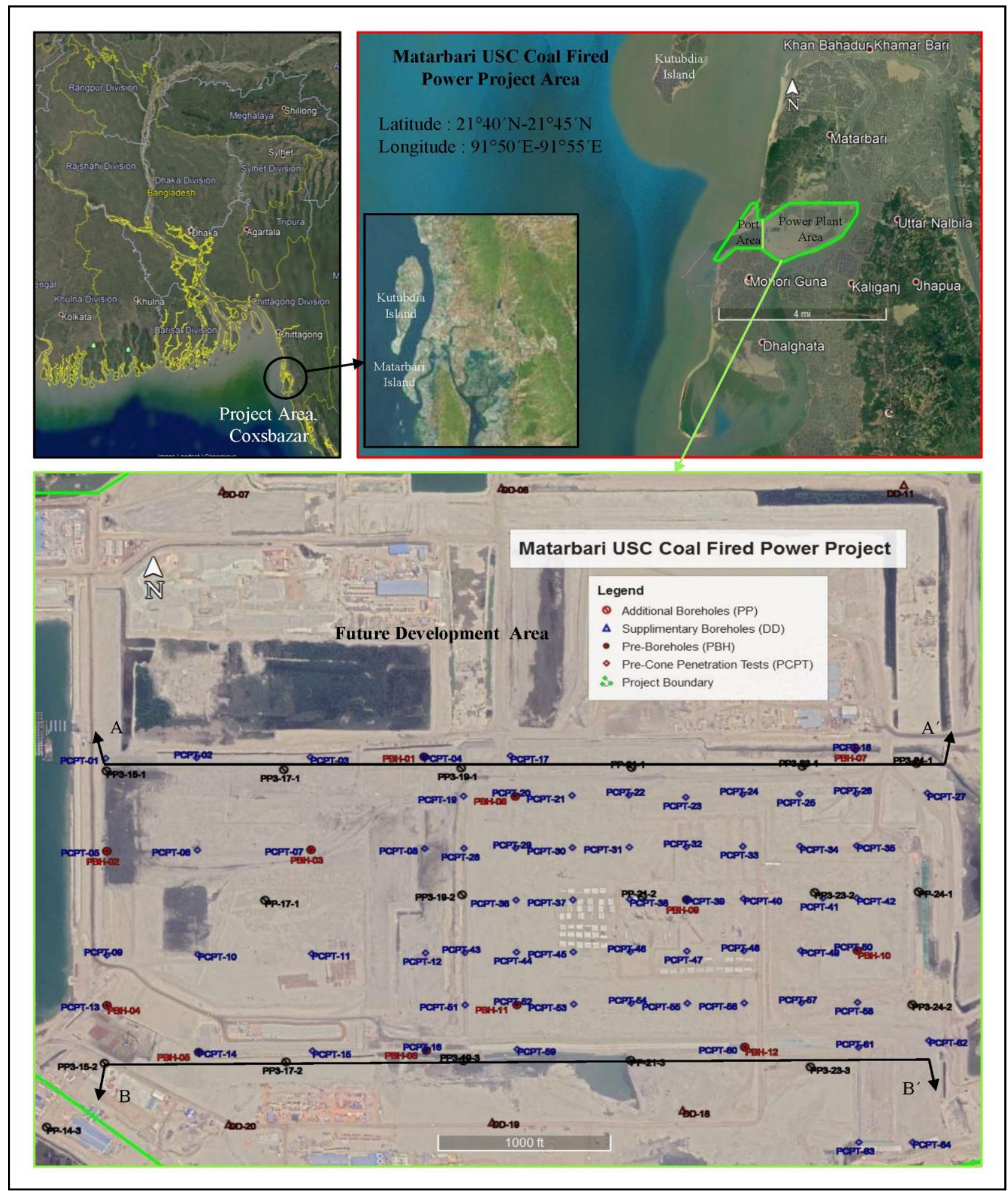

Fig. 1:- Location map of the project site and surrounding area. 
Fig. 2. shows general geology around the site. A general geological trend which is distributed parallel to the NNW-SSE trended coastline is seen from this map. The anticlines from the NNW-SSE trended hill ranges, and the hilly area occupies the northeastern part of the site. Maheskhali Island underlain gradually by Neogene Boka Bil
Formation (Tbb) and Tipam Sandstone (Tt), Neogene to Pleistocene Girujuan Clay (QTg) and Pleistocene and Pliocene Dupi Tila Formation (QTdt). There is beach sand (csd) of Holocene distributes along the seaside. Stratigraphic units summarized in Table 1 .

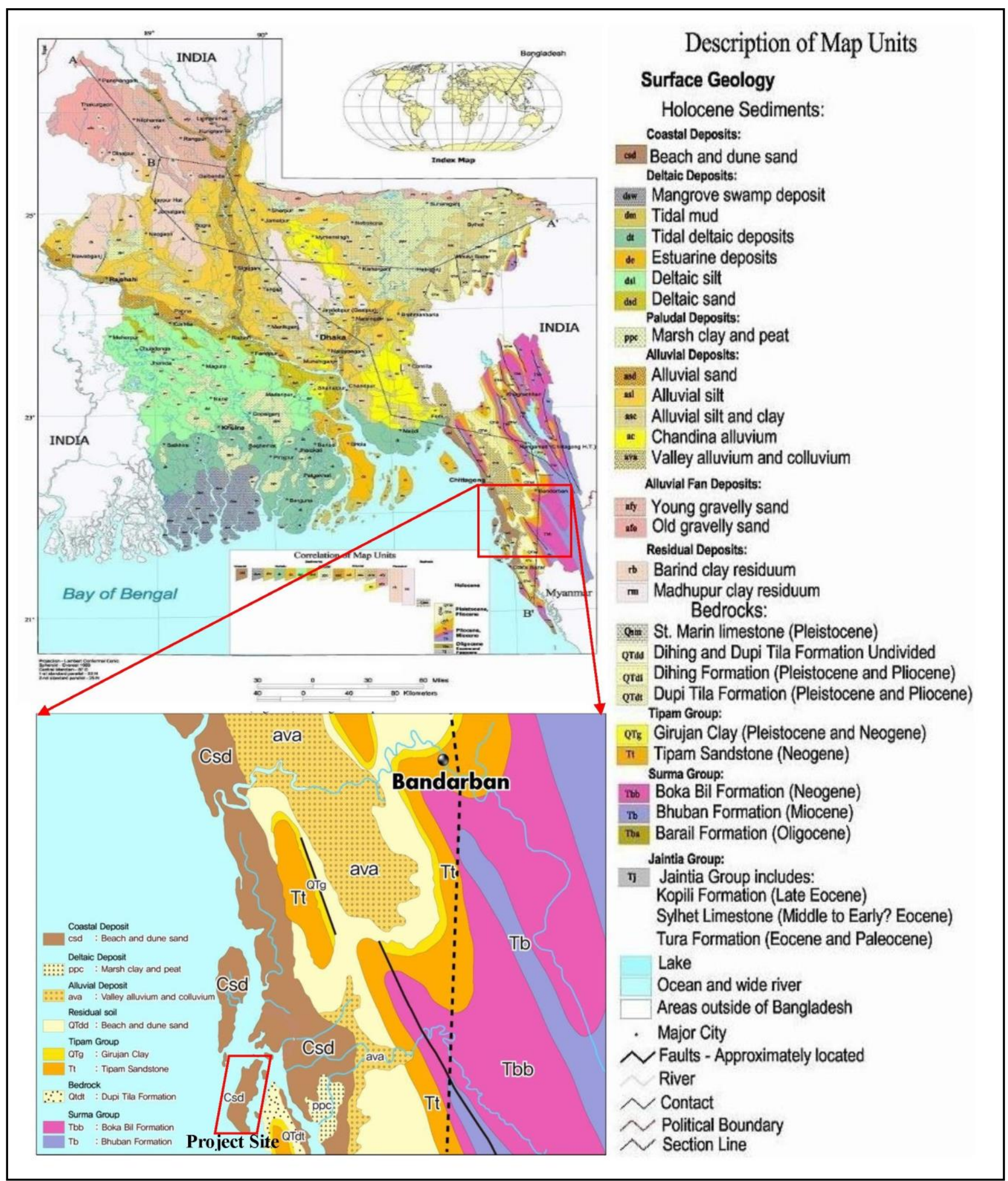

Fig. 2:- General geology around the project site modified by the Geological Survey of Bangladesh (Alam et al., 1990). 
ISSN No:-2456-2165

\begin{tabular}{|c|c|c|c|}
\hline Stage & Formation & Symbol & Lithology \\
\hline \multirow{2}{*}{ Holocene } & Coastal Deposits & csd & \multirow{2}{*}{ Silt, Sand, Gravel and Clay } \\
\hline & Deltatic Deposits & ppc & \\
\hline Pleistocene/Pliocene & Dupi Tila Formation & QTdt & Sandstone, Siltstone and Conglomerate \\
\hline Pleistocene/Neogene & Girujan Clay & QTg & Silty Shale, Shale and Claystone \\
\hline \multirow{2}{*}{ Neogene } & Tipam Sandstone & $\mathrm{Tt}$ & Pebbly Sandstone, Siltstone and Shale \\
\hline & Boka Bil Formation & Tbb & Marine Pyrite Shale, Siltstone and Sandstone, marine fossils \\
\hline
\end{tabular}

Table 1:- The major stratigraphic units in the vicinity of the site modified by the Geological Survey of Bangladesh (Alam et al., 1990).

\section{MATERIALS AND METHOD}

The geotechnical field investigations were conducted for collecting soil samples and in situ ground information. Thirty-five boreholes and Sixty-four Cone penetration tests (CPT) were conducted in this study area with a depth range from $20 \mathrm{~m}$ to $45 \mathrm{~m}$. The existing ground elevation varies from mean sea level $-0.15 \mathrm{~m}$ to $3.42 \mathrm{~m}$. Standard penetration tests (SPT) were performed at $1.5 \mathrm{~m}$ (PP \& DD) and $2.0 \mathrm{~m}(\mathrm{PBH})$ intervals and collection of disturbed and undisturbed soil samples were carried out in each borehole. Laboratory tests were performed on the collected undisturbed and disturbed soil samples. The relevant ASTM standard is used to carry out the works (ASTM International, previously "American Society for Testing and Materials"). In this research, soil investigation factual data was mainly used for detailed discussions, analysis and interpretation. Soil investigation factual data of SPT and CPT (SPT's at 16 boreholes \& 13 CPT's) were used for generating soil profiles of the study area.

Standard Penetration Tests (SPT) were performed under ASTM D 1586 (2011). The purpose of SPT's was to determine the relative density or consistency of the subsoil and to obtain disturbed samples for visual and laboratory soil classification. Split Spoon sampler was used to collect disturbed soil samples. Undisturbed (UD) soil samples were collected by the two types of undisturbed samplers: Hydraulic Piston (HP) Sampler and Shelby Thin-Walled Tube Sampler (TW). Undisturbed samples from very soft to soft soil layers with SPT, N-values of generally fewer than 4.0 obtained by using Hydraulic Piston Sampler (HP) according to ASTM D 6519 (2015). A thin-wall tube of this sampler was pushed into the soil by hydraulic thrust supplied by the water pump through the drilling rod. Shelby thinwalled tube sampler used to collect the undisturbed samples; from medium-stiff to stiff soil layers with SPT, N-values between 4.0 and 15.0 by following ASTM D 1587 (2008). The thin wall tube was pushed into the soil by the hydraulic system of a drilling rig. The CPT's conducted using a crawler type CPT penetrometer with GEOMIL Piezocone System to obtain depth profiles of the Cone Resistance, Sleeve Friction, and Porewater Pressure. The CPT's carried out based on ASTM D 5778 (2012). The standard procedure was summarized in Table 2 for the laboratory tests.

\begin{tabular}{|c|c|c|}
\hline Test Name & Description & Test Standard \\
\hline \multirow{4}{*}{ Index Property Test } & Natural Water Content & ASTM D 1622, 2010 \\
\cline { 2 - 3 } & Wet and Dry Density & ASTM D 7263, 2009 \\
\cline { 2 - 3 } & Specific Gravity & ASTM D 854, 2002 \\
\cline { 2 - 3 } & Atterberg Limits & ASTM D 4318-2001 \\
\cline { 2 - 3 } Mechanical Property Test & Grain Size Distribution (Sieve \& Hydrometer) & ASTM D2850, 2015 \\
\cline { 2 - 3 } & Unconsolidated Undrained Triaxial Test & ASTM D 2435, 2011 \\
\hline
\end{tabular}

Table 2:- The standard for laboratory soil tests.

\section{RESULTS AND DISCUSSION}

The analyzed results are discussed based on the soil investigation factual data. The geotechnical issues or problems addressed in this research as follows: Geotechnical conditions and generalized soil stratifications along the project area; stability of foundation soil in terms of shear strength or bearing capacity; settlement of foundations soils during and after the construction. Also, Geotechnical parameters discussed for the proposed design and construction of the engineering structure. Finally, geotechnical recommendations are suggested based on the foundation types and depths concerning the settlement of foundation soils.

The Atterberg limits, moisture content, specific gravity, density, and grain size with hydrometer tests, represent basic and index properties of soils (Fig. 5 to 9 and Table 5). All of these tests are conducted for determining the characteristics and classification of soils of the studied area. Mechanical 
properties are evaluated from the triaxial compression and one-dimensional consolidation test results.

Unconsolidated undrained (UU) triaxial compression tests are carried out on fine-grained (or cohesive) soils to determine the load-bearing capacity and shear strength parameters of the foundation soils. The standard onedimensional consolidation test is performed to estimate the consolidation parameters of the foundation soil. Mechanical properties of soil are determined for design and ground improvement purposes (Figs. 12 to 15 and Table-5) of the project area.

The soils are typically divided into two specific groups, i.e., cohesive clayey and non-cohesive sandy soil. The general description of soil layers is presented briefly in table 3 and classified into table 4. The general cross-section produced based on the borehole lithology and Cone penetration test results. The cross-section of the northern (AA') and southern (A-B') parts of the study area shown in Figures 3 and 4.

\begin{tabular}{|c|c|}
\hline $\begin{array}{l}\text { Soil } \\
\text { layers }\end{array}$ & Description of soils \\
\hline Ac- 1 & $\begin{array}{l}\text { The Ac-1 layer predominantly consists of dark gray to gray CLAY with the trace of mica, seashell fragments, organic } \\
\text { matters, and decayed wood. Fine to medium-grained sand layers occasionally interbedded in Ac- } 1 \text {. The layer } \\
\text { encountered from ground level or underfilled layer and found at every borehole in this area. The thickness of the layer is } \\
\text { from } 2.4 \mathrm{~m} \text { to } 10.2 \mathrm{~m} \text {. The SPT, N-values ranges from } 0 \text { to } 4 \text {, and the consistency of the layer is very soft to soft. } \\
\text { Relatively high qc with } 1 \text { to } 5 \mathrm{MPa} \text { encountered at the top of Ac-1. It could be a dried or consolidated layer of Ac- } 1 \text { due } \\
\text { to sun drying or heavy traffic. }\end{array}$ \\
\hline Ac-2 & $\begin{array}{l}\text { The Ac- } 2 \text { consists of dark gray to gray CLAY, Sandy CLAY and SILT with fine-grained Sand and trace of mica and } \\
\text { seashell fragments. This layer is generally encountered underneath Ac- } 1 \text { extensively at the site. The thickness of the } \\
\text { layer is from } 1.0 \mathrm{~m} \text { to } 7.6 \mathrm{~m} \text {. The range of SPT N-values is from } 4 \text { to } 8 \text {, and the consistency of the layer is firm. Ac-2 } \\
\text { below As- } 2 \text { with a thickness of more than } 4.0 \mathrm{~m} \text { and considered as Ac-3. }\end{array}$ \\
\hline Ac-3 & $\begin{array}{l}\text { The Ac-3 layer consists of mainly dark gray to gray CLAY with Sand, Sandy CLAY, SILT with Sand and Sandy SILT } \\
\text { with fine to medium-grained sand and trace of mica fragments, seashell fragments and organic matters. Some scattered } \\
\text { Gravel found in this layer at borehole PBH- } 02 \text {. This layer is generally encountered underneath Ac- } 2 \text { extensively at the } \\
\text { site. The thickness of the layer is from } 1.0 \mathrm{~m} \text { to } 5.0 \mathrm{~m} \text {, and the range of SPT N-values is from } 8 \text { to } 15 \text {. The consistency of } \\
\text { the layer is stiff. }\end{array}$ \\
\hline Ac- 4 & $\begin{array}{l}\text { The Ac- } 4 \text { consists of dark gray SILT with fine to coarse-grained Sand and trace of mica and seashell fragments. The } \\
\text { layer is underlying the Ac- } 3 \text { or As- } 2 \text { layer in the borehole PBH- } 04 \text { and CPT at PCPT-13 and PCPT-50. The thickness of } \\
\text { the layer is approximately } 2.0 \mathrm{~m} \text {. The range of SPT N-values is from } 15 \text { to } 30 \text {; the consistency of the layer is very stiff. }\end{array}$ \\
\hline As-1 & $\begin{array}{l}\text { The As-1 layer consists of dark grey Clayey SAND and Silty SAND with the trace of mica fragments and laminated } \\
\text { with clay layers. Sand is predominantly fine-grained. The layer encountered below the Ac- layer in the borehole PP-21- } \\
\text { 1, PP-21-3, PP3-19-2, PP3-23-2, PP3- 24-1and PBH-09 and in the CPT at PCPT-08, PCPT-26, PCPT-27, PCPT-35, } \\
\text { PCPT-39, PCPT-41, PCPT-53 to PCPT-55. The thickness of the layer is from } 0.3 \mathrm{~m} \text { to } 5.8 \mathrm{~m} \text {. The SPT N-values ranged } \\
\text { from } 0 \text { to 10; the relative density of the layer is very loose to loose. The cone resistance is generally } 3 \text { MPa or less. }\end{array}$ \\
\hline As-2 & $\begin{array}{l}\text { The As- } 2 \text { consists of dark gray to gray Clayey SAND, Silty SAND and Sand with CLAY. The layer observed in this site } \\
\text { area, and it is generally underlying the Ac- } 1 \text { or Ac-2 layer. Sand is predominantly fine-grained and laminated with clay } \\
\text { and silt layers. Trace of mica fragments, seashell fragments, and organic matters presented in this layer. The layer } \\
\text { thickness is between } 0.8 \mathrm{~m} \text { to } 11.2 \mathrm{~m} \text {. The SPT N-values ranged from } 10 \text { to } 30 \text { blows; the relative density is medium } \\
\text { dense. The cone resistance is generally } 3 \text { to } 9 \mathrm{MPa} \text {. }\end{array}$ \\
\hline As-3 & $\begin{array}{l}\text { The As-3 layer consists of dark gray to gray SAND with a trace of seashell fragments. The layer is underlying the Ac- } 3 \\
\text { layer at boreholes PBH-02 and CPTs PCPT-26, PCPT-28, PCPT-29, PCPT-35 and PCPT- } 37 \text {. The thickness of the layer } \\
\text { is } 0.8 \mathrm{~m} \text { to } 4.1 \mathrm{~m} \text {. The SPT N-values ranged from } 30 \text { to } 50 \text {; the relative density is dense. The cone resistance of the layer } \\
\text { is generally } 9 \text { to } 15 \mathrm{MPa} \text {. }\end{array}$ \\
\hline Dc & $\begin{array}{l}\text { In general, the Dc layer is underlying the Ac- } 3 \text { or As- } 2 \text { layer. The layer consists of dark gray to gray, CLAY and SILT } \\
\text { with fine-grained laminated Sand, the trace of mica fragments and decayed wood. This layer is generally encountered } \\
\text { underneath Ac- } 3 \text { or As- } 2 \text { extensively at the site. The thickness of the layer calculated in this investigation is from } 0.6 \mathrm{~m} \\
\text { to } 8.1 \mathrm{~m} \text {. The SPT N-value is more than } 30 \text {, and the consistency of the layer is hardened. }\end{array}$ \\
\hline Ds & $\begin{array}{l}\text { In general, the Ds layer identified underneath the Dc layer. This layer is composed of Silty SAND and SAND with fine } \\
\text { to medium-grained Sand, trace of mica fragments and laminated of clay layers. The colour of the layer is predominantly } \\
\text { dark gray to gray and occasionally encountered light brown to brown and yellowish-brown. The layer found at boreholes } \\
\text { PP-21-1, PP-21-3, PBH-02 to PBH-08, and PBH-12. And also CPTs at PCPT-16, PCPT-18, PCPT-51, and PCPT-60. } \\
\text { The thickness of the layer determined in this investigation is ranging from } 1.7 \mathrm{~m} \text { to } 4.5 \mathrm{~m} \text {. The SPT N-values are more } \\
\text { than } 50 \text { blows, and the relative density is very dense. The cone resistance of the layer is generally } 15 \mathrm{MPa} \text { or more. }\end{array}$ \\
\hline
\end{tabular}

Table 3:- General description of the project areas soils. 
ISSN No:-2456-2165

\begin{tabular}{|l|l|l|l|l|l|l|}
\hline \multicolumn{2}{|l|}{ Land Area } & \multicolumn{3}{l|}{ Based on SPT } & \multicolumn{2}{l|}{} \\
\hline $\begin{array}{l}\text { Soil } \\
\text { Layers }\end{array}$ & Thickness $(\mathbf{m})$ & Soil Type & N-value & $\begin{array}{l}\text { Soil Type } \\
\text { (Zone) }\end{array}$ & $\begin{array}{l}\text { Undrained Shear } \\
\text { Strength }(\mathrm{kPa})\end{array}$ & $\begin{array}{l}\text { Cone } \\
\text { (MPa) }\end{array}$ \\
\hline Ac-1 & $2.4-10.2$ & Clayey & $\mathrm{N} \leq 4$ & $1-4$ and 9 & $<25$ & - \\
\hline Ac-2 & $1.0-7.6$ & Clayey & $4<\mathrm{N} \leq 8$ & $1-4$ and 9 & $25-50$ & - \\
\hline Ac-3 & $1.0-5.0$ & Clayey & $8<\mathrm{N} \leq 15$ & $1-4$ and 9 & $50-125$ & - \\
\hline Ac-4 & 2.0 & Clayey & $15<\mathrm{N} \leq 30$ & $1-4$ and 9 & $125-250$ & - \\
\hline As-1 & $0.3-5.8$ & Sandy & $\mathrm{N} \leq 10$ & 5 to 8 & - & $\leq 3$ \\
\hline As-2 & $0.8-11.2$ & Sandy & $10<\mathrm{N} \leq 30$ & 5 to 8 & - & $3<\mathrm{N} \leq 9$ \\
\hline As-3 & $0.8-4.1$ & Sandy & $30<\mathrm{N} \leq 50$ & 5 to 8 & - & $9<\mathrm{N} \leq 15$ \\
\hline Dc & $0.6-8.1$ & Clayey & $30<\mathrm{N}$ & $1-4$ and 9 & $>250$ & - \\
\hline Ds & $1.7-4.5$ & Sandy & $50<\mathrm{N}$ & 5 to 8 & - & $15<\mathrm{N}$ \\
\hline
\end{tabular}

Table 4:- The general classification of the project areas soils.

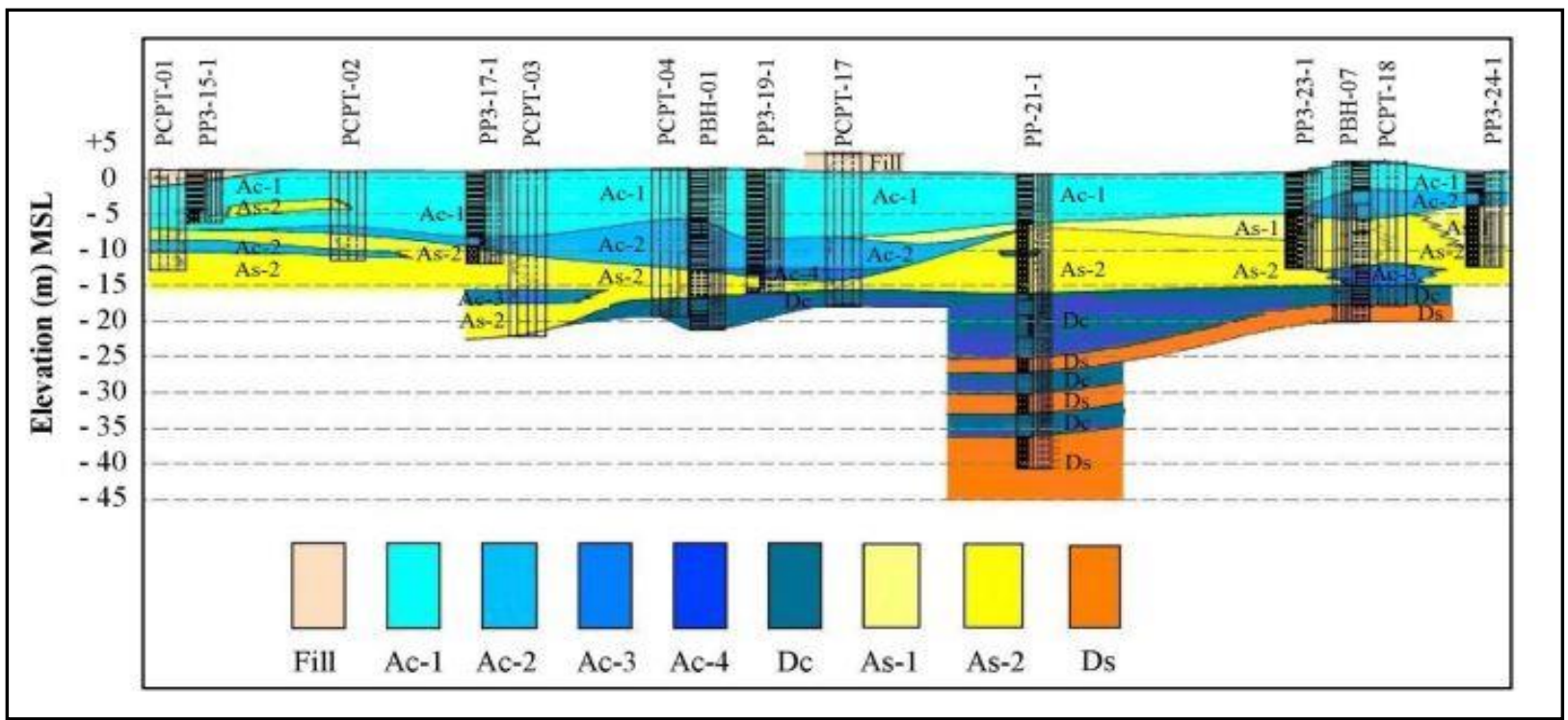

Fig. 3:- The generalized soil profile of the Northside (A-A') of the project area.

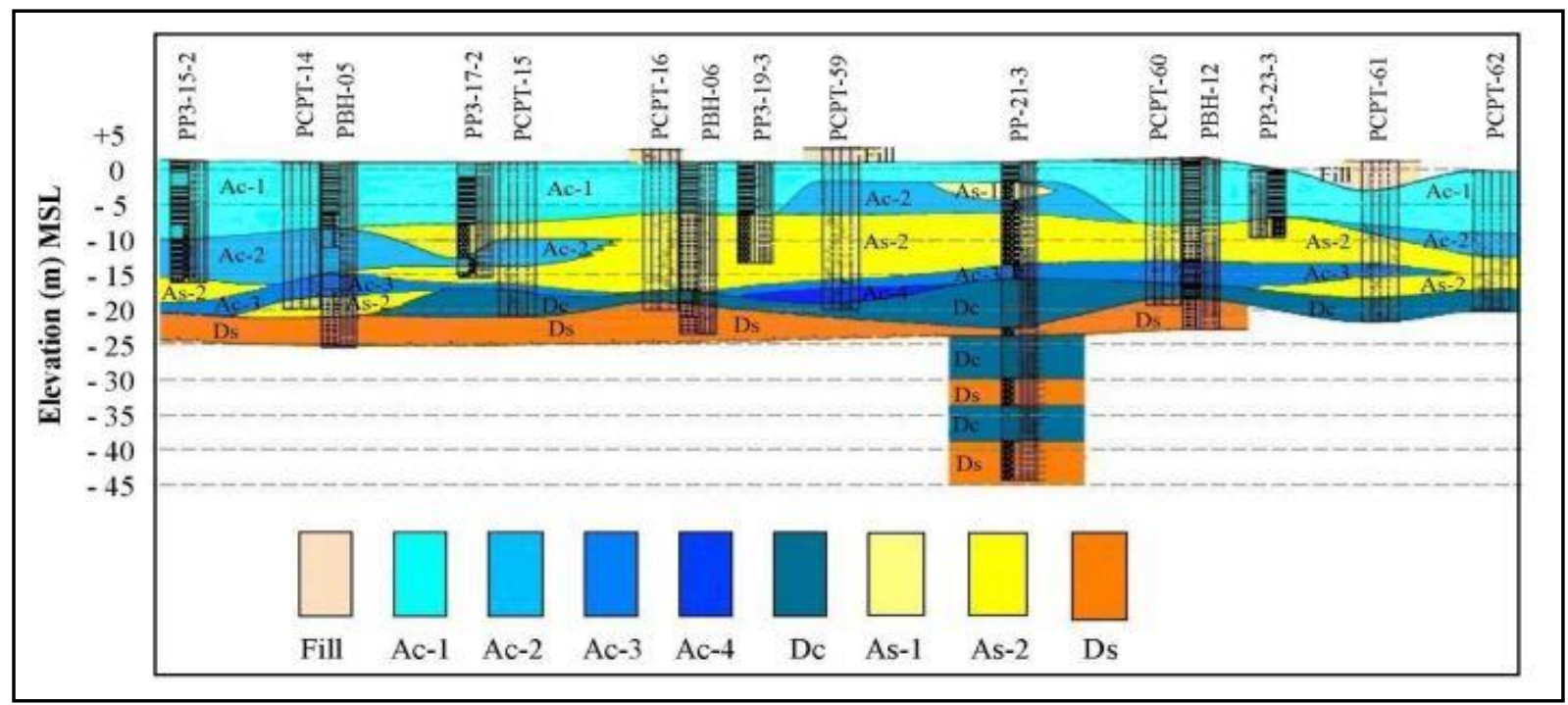

Fig. 4:- The generalized soil profile of the Southside (B- B') of the project area.

The characteristics of soil are evaluated and classified by the basic and index properties. The graphic representation of basic and index properties against the variation of depth established the soils mainly composed of cohesive clay and non-cohesive sandy soils. The grain size distribution curve suggests the soils are predominantly composed of Sand, Silt, Clay and Colloids particles (Fig. 5). It indicates the soils are poorly graded and ranged from 1.0 to $0.001 \mathrm{~mm}$. The soils are 
gray to dark gray and occasionally encounter dark brown and brownish-gray, mainly coastal beach sand and composed of SAND, SAND with Silt, Silty SAND, Clayey SAND and Gravelly SAND. The percentages of Gravel, Sand, Silt, Clay and Colloids particle are variable with depths shown in Fig. 6. In upper parts, Sand is around $0.0-60 \%$, but in the lower parts extends around $95 \%$.

Silt is around $20-50 \%$ in the upper parts and 5.0-65\% in lower parts. Clay and Colloids are 22-65\% in upper parts and $15-38 \%$ in lower parts. Few percentages (1.0-6.0) of gravel are found within the sandy soil in lower part. The percentages of soil particles indicate that the sand and silt percentages increased with increasing depth, and clay percentages decreased with increasing depth.

The moisture content, specific gravity, density and Atterberg limits (Fig. 7 and Tab. 5) suggest a sharp variation in soils from upper $(0.0-10 \mathrm{~m})$, middle $(10-18 \mathrm{~m})$ and the lower parts $(>18 \mathrm{~m})$. The upper soil is mainly dominated by cohesive clayey soil. The middle part contains a mixture of cohesive clay and non-cohesive sand and silt. Although, noncohesive Sandy soils dominate the lower portion.

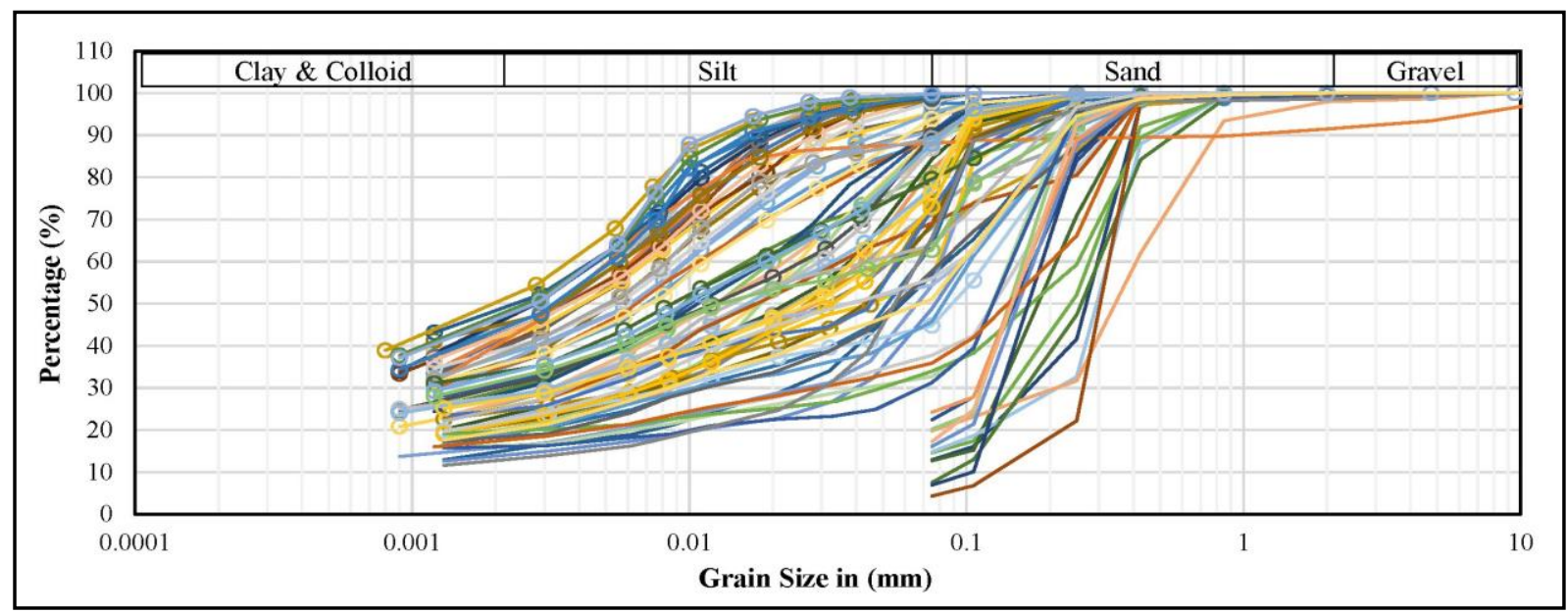

Fig. 5:- The grain size distribution of soils of the project area.

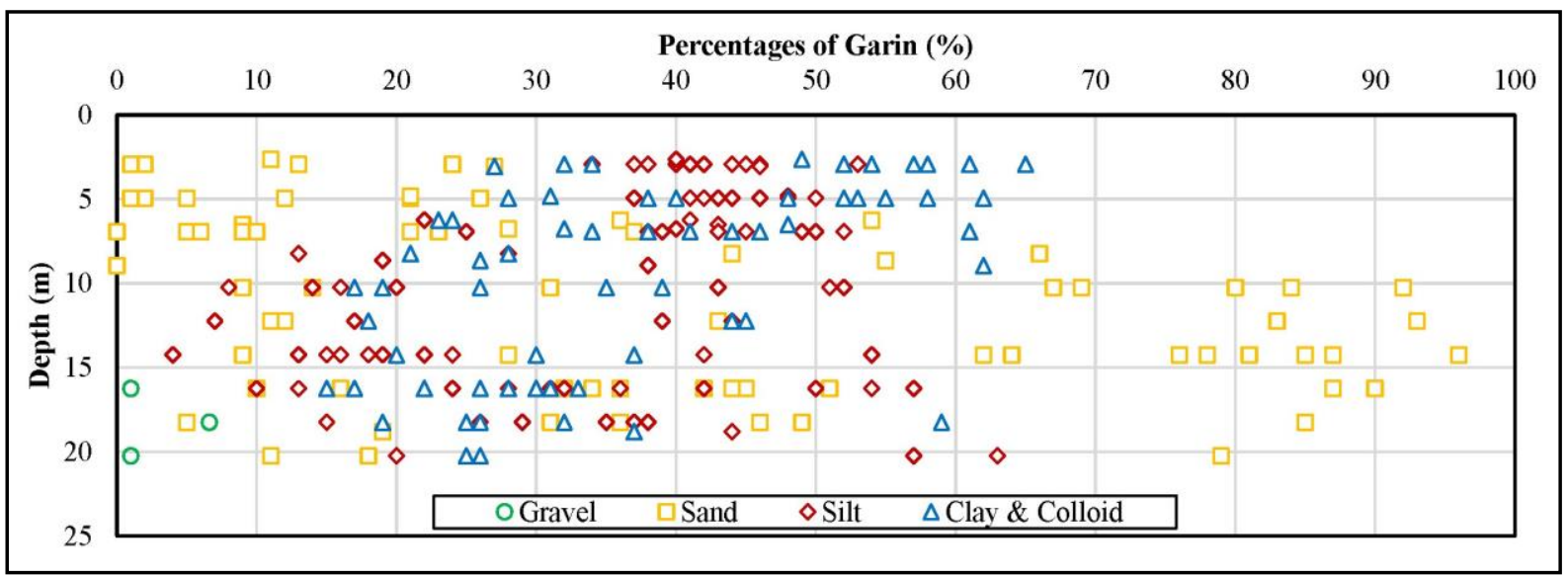

Fig. 6:- The percentages of soil particles variation against the depth of the project area.

The cohesive clayey soils are divided into Ac-1, Ac-2 Ac-3, Ac-4 and Dc units based on the basic and index properties (Figure-7). The upper part $(0.0-10 \mathrm{~m})$ of cohesive soils mainly composed of Ac-1 including As-1 with high moisture (28-66) content, low dry (1.12-1.53) and wet (1.711.97) density, high specific gravity $2.7-2.77$ with a range of plastic limit (19-37), liquid limit (30-69) and plasticity index (8.0-35). These properties suggest that the soils mainly composed of very soft to soft, low to highly plastic CLAY, Silty CLAY, CLAY with Silt and Sand. The middle part (10$18 \mathrm{~m})$ consists of Ac-2 and Ac-3 with moisture content (2238 , specific gravity (2.60-2.70), plastic limit (16-30), liquid limit (28-44) and plasticity index (9-21) are suggesting these soils mainly composed of the firm to stiff, medium plastic
CLAY, Sandy CLAY and SILT, Clayey Sand or Sand-Silt mixture. The lower part $(>18)$ mainly consists of cohesive soils (Ac-4 and Dc) with low moisture (24-31) content, low specific gravity 2.65 to 2.67 , plastic limit (22-34), liquid limit (35-60) and plasticity index (13-26) are suggesting soils composed of stiff to hard, medium to highly plastic CLAY and SILT with Sand. According to the Unified Soil Classification System (ASTM D 2487, 2017), the plasticity chart shows that the cohesive soils are organic to inorganic clay and lies above the A-line (Figure 8). The chart suggests these soils mainly soft to very soft, medium to highly plastic (CL-OL and $\mathrm{CH}-\mathrm{OH}$ ) Clayey soils. Chemically these Clay soils are composed of Kaolinite and Illite minerals. 
ISSN No:-2456-2165

\begin{tabular}{|c|c|c|c|c|c|c|c|c|c|c|c|c|}
\hline \multicolumn{13}{|c|}{ Index or Physical properties of land area soil } \\
\hline \multirow{2}{*}{$\begin{array}{l}\text { Soil } \\
\text { Layer }\end{array}$} & \multicolumn{2}{|c|}{$\begin{array}{c}\text { Natural Water } \\
\text { Content }(\%)\end{array}$} & \multicolumn{2}{|c|}{$\begin{array}{c}\text { Wet Density } \\
(\mathrm{Mg} / \mathrm{m3})\end{array}$} & \multicolumn{2}{|c|}{$\begin{array}{c}\text { Plastic Limit } \\
(\%)\end{array}$} & \multicolumn{2}{|c|}{ Liquid Limit (\%) } & \multicolumn{2}{|c|}{$\begin{array}{c}\text { Plasticity Index } \\
(\%)\end{array}$} & \multicolumn{2}{|c|}{ Liquidity Index } \\
\hline & Range & Av. & Range & Av. & Range & Av. & Range & Av. & Range & Av. & Range & Av. \\
\hline Ac-1 & $28-56$ & 43.3 & $\begin{array}{l}1.70- \\
1.97\end{array}$ & 1.82 & 19-37 & 24.3 & $30-69$ & 47.7 & $8-35$ & 22.6 & $0.43-1.38$ & 0.87 \\
\hline Ac-2 & 20-39 & 33.3 & $\begin{array}{l}1.83- \\
1.96\end{array}$ & 1.9 & $16-30$ & 21.36 & $28-44$ & 36 & $9-21$ & 15.45 & $0.18-1.19$ & 0.87 \\
\hline Ac-3 & $24-35$ & 288 & 1.87 & 1.87 & $16-23$ & 19.85 & $29-43$ & 35 & $12-21$ & 15.14 & $0.05-0.82$ & 0.54 \\
\hline Ac-4 & 24.9 & 24.9 & - & - & 22 & 22 & 35 & 35 & 13 & 13 & 0.22 & \\
\hline As-1 & -32 & & - & - & - & - & - & - & 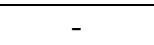 & - & - & - \\
\hline As-2 & $17-36$ & 9 & 1.95 & 1.95 & - & - & - & - & - & - & - & - \\
\hline Dc & $24-31$ & 27.5 & - & - & $20-34$ & 25.7 & $37-60$ & 45.3 & $14-26$ & 19.7 & - & \\
\hline \multicolumn{13}{|c|}{ Mechanical properties of land area soils } \\
\hline \multirow{2}{*}{$\begin{array}{l}\text { Soil } \\
\text { Layer }\end{array}$} & \multicolumn{2}{|c|}{$\begin{array}{c}\text { Undrained } \\
\text { Shear Strength, } \\
\mathrm{Su}_{\mathrm{u}}(\mathbf{k P a})\end{array}$} & \multicolumn{2}{|c|}{$\begin{array}{l}\text { Shear Strength } \\
\text { Parameter }\end{array}$} & \multicolumn{2}{|c|}{$\begin{array}{l}\text { Natural Void } \\
\text { Ratio }\left(\mathbf{e}_{0}\right)\end{array}$} & \multicolumn{2}{|c|}{$\begin{array}{l}\text { Compression } \\
\text { Index }\left(\mathbf{C}_{c}\right)\end{array}$} & \multicolumn{2}{|c|}{$\begin{array}{l}\text { Recompression } \\
\text { Index }\left(\mathbf{C}_{\mathbf{r}}\right)\end{array}$} & \multicolumn{2}{|c|}{$\begin{array}{c}\text { Preconsolidation } \\
\text { Pressure (P'c) } \\
\text { kPa }\end{array}$} \\
\hline & Range & Av. & $\begin{array}{l}\text { Range } \\
\text { of c' } \\
(\mathrm{kPa})\end{array}$ & $\begin{array}{l}\text { Range } \\
\text { of } \varphi \text { ' } \\
\text { (deg) }\end{array}$ & Range & Av. & Range & Av. & Range & Av. & Range & Av. \\
\hline Ac-1 & $12-68$ & 27 & $6-7$ & 29-30 & $\begin{array}{c}0.77- \\
1.42\end{array}$ & 1.14 & $0.09-0.54$ & 0.31 & $0.02-0.14$ & 0.08 & $48-160$ & 91 \\
\hline Ac-2 & - & - & 6 & 31 & - & - & - & - & - & - & - & - \\
\hline
\end{tabular}

Table 5:- Summary of the index or physical and mechanical properties of the project areas soil.

The liquidity index is generally a good indicator of stress history. A liquidity index close to unity indicates normally consolidated soils, but close to zero shows heavily over consolidated soils. The liquidity index values averages for Ac-1 (0.87), Ac-2 (0.87), Ac-3 (0.54) and Ac-4 (0.22). It suggests normal to slight consolidation for soil layer Ac-1 and Ac-2, and moderate to high levels of over-consolidation for soil layers Ac-3 and Ac-4.

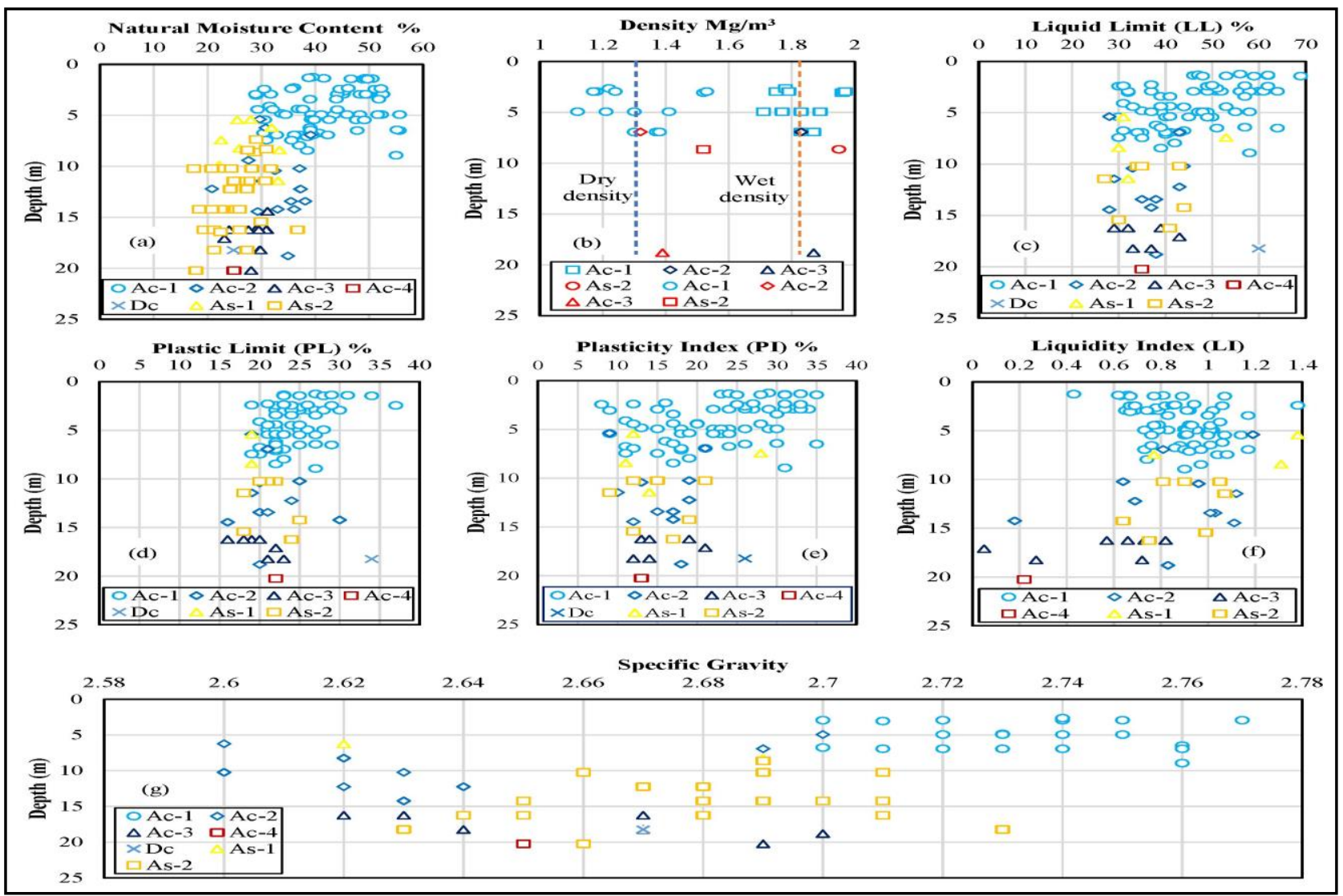

Fig. 7:- Basic and index properties of soil compared with the depth of the project area. (a) Natural Moisture Content, (b) Density (Dry \& Wet), (c) - (f) Atterberg Limits and (g) Specific Gravity. 


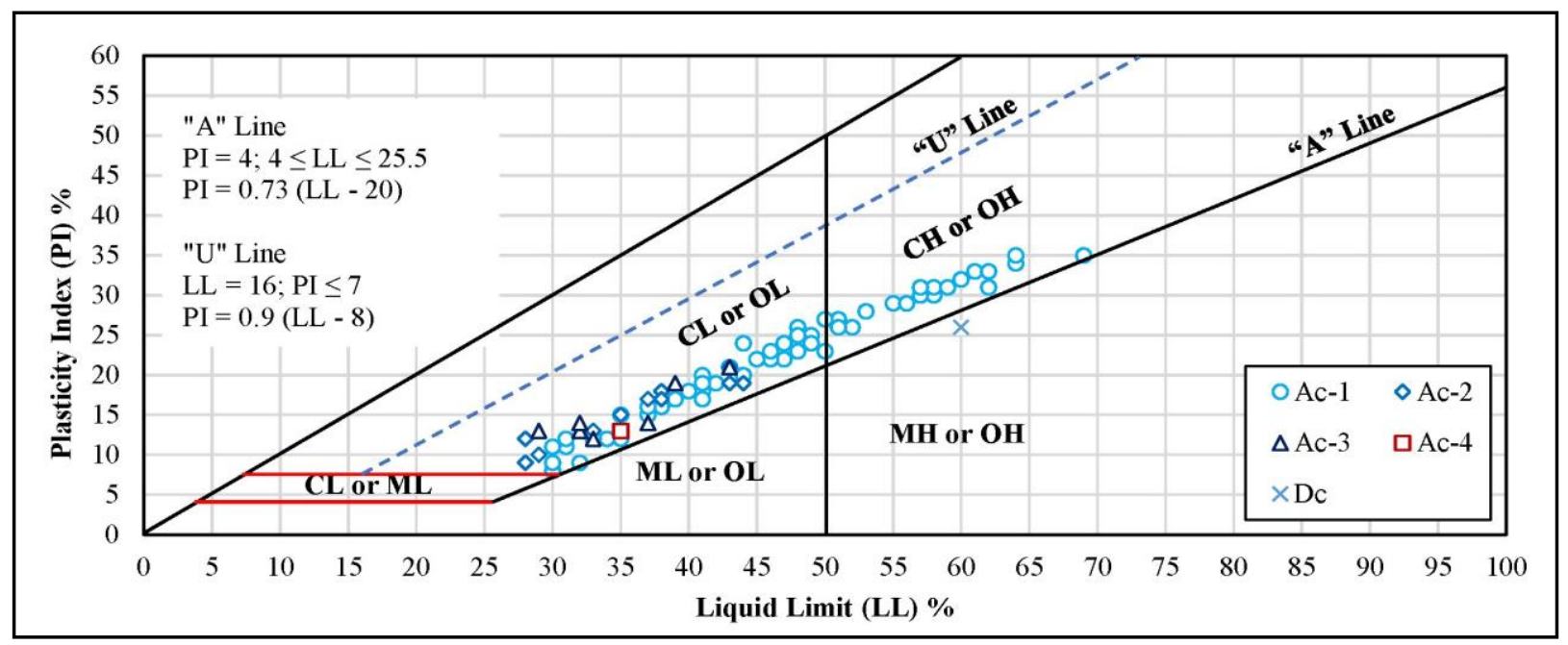

Fig. 8:- Soil classification based on the Unified soil Classification System (USCS) of the project area.

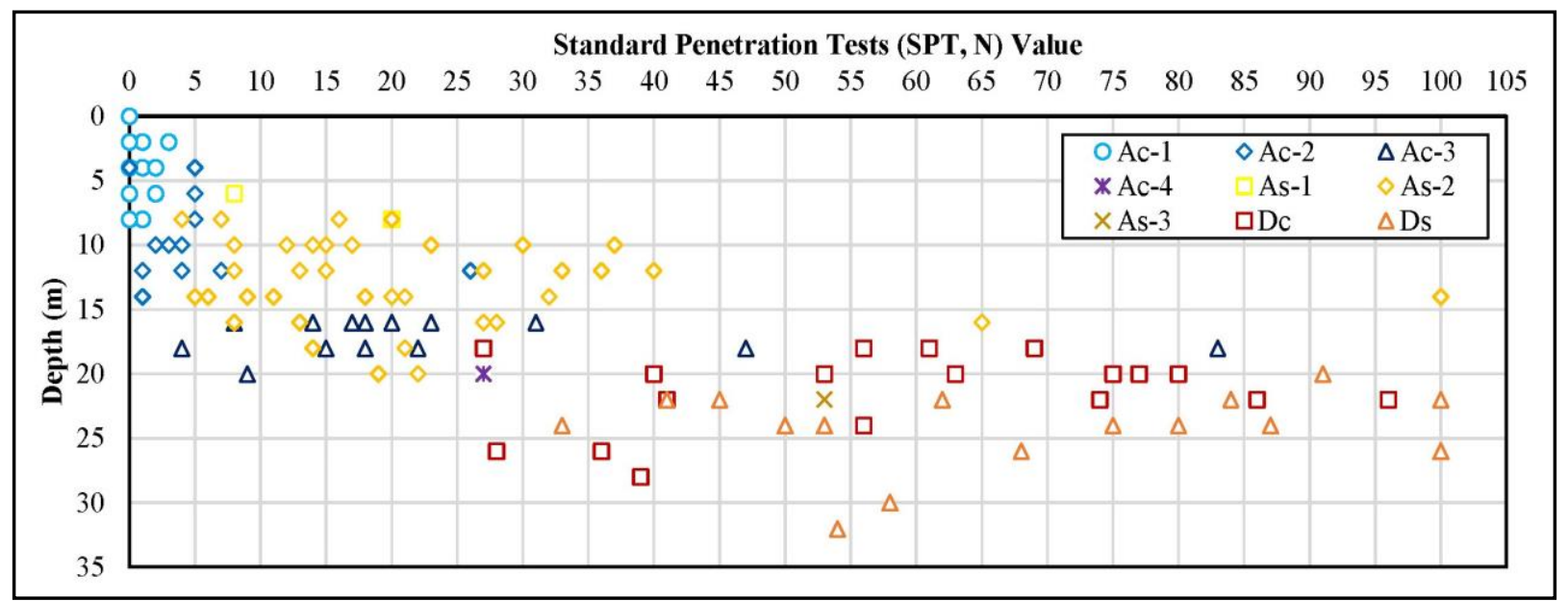

Fig. 9:- Variation of SPT (N) values comparing the depth and consistency of soils.

Fig. 9 shows the consistency of soils. The non-cohesive Sandy soils are classified into As-1, As-2, As-3, and Ds unit. The relative density of non-cohesive soils from the standard penetration test indicates the soil layer As- 1 is very loose to loose $(\mathrm{N}<10)$ up to the depth of $6.0-8 \mathrm{~m}$ and finds within the Ac-1 layer of the site. The low moisture content (22-32) and specific gravity (2.62-2.69) suggests these soils are Sand dominated Silty Sand or Clayey Sand. The As-2 layer indicates medium dense to dense (10-40) sandy soils found within the $8.0-20 \mathrm{~m}$ depth and dense to very dense As-3 and Ds layer found $>20 \mathrm{~m}$ depth. The moisture content (17-36), dry density (1.52), wet density (1.95) and specific gravity (2.63-2.71) suggest these soils are Sand dominated Silty Sand or Clayey Sand and mixture of Clay and Sand. The Ds observes at limited boreholes below As-3. The SPT (N) values gradually increased with increasing depth (Fig. 9). These values suggested the non-cohesive soils very loose to loose at the upper part and dense to very dense at lower parts.

The most significant advantage of the CPT is its ability to provide a continuous soil profile with minimum error. Conclusions about soil types are established from the CPT results. The Robertson et al., (1986) SBT chart, updated in Robertson (2010), is the most commonly used soil behavior type chart. The Robertson et al., (1986) chart uses the corrected cone resistance $\left(\mathrm{q}_{\mathrm{t}}\right)$, and the friction ratio $\left(\mathrm{R}_{\mathrm{f}}\right)$, and has 12 soil types (Figure 10). Robertson (2010) provides an update in terms of dimensionless cone resistance $\left(\mathrm{q}_{\mathrm{c}} / \mathrm{p}_{\mathrm{a}}\right)$ and $\left(\mathrm{R}_{\mathrm{f}}\right)$ on $\log$ scales. It also reduces the number of soil behavior types to 9, matching the Robertson (1990) chart (Figure 11). The table below summarizes the unification of the 12 soil types to the 9 soil types (Robertson, 1990). According to the SBT chart (Robertson et al., 1986), the soils have fully covered the area marked as 1 to 9 and some portion of 10 (Figure 10). Whereas, in the case of the $\mathrm{SBT}_{\mathrm{n}}$ chart (Robertson, 1990), the soils fully covered the area numbered as 1, 2, 3, 4, 5, 6, and 7 (Figure 11). The common description and comparison of soils summarized in table 6 . Therefore, it established the soils of this area consist of sensitive finegrained organic CLAY, Silty CLAY, Clayey SILT, CLAY with Sand, SILT with Sand, and Sandy CLAY, SAND, SAND with Silt, Silty SAND, Clayey SAND and Gravelly SAND. 


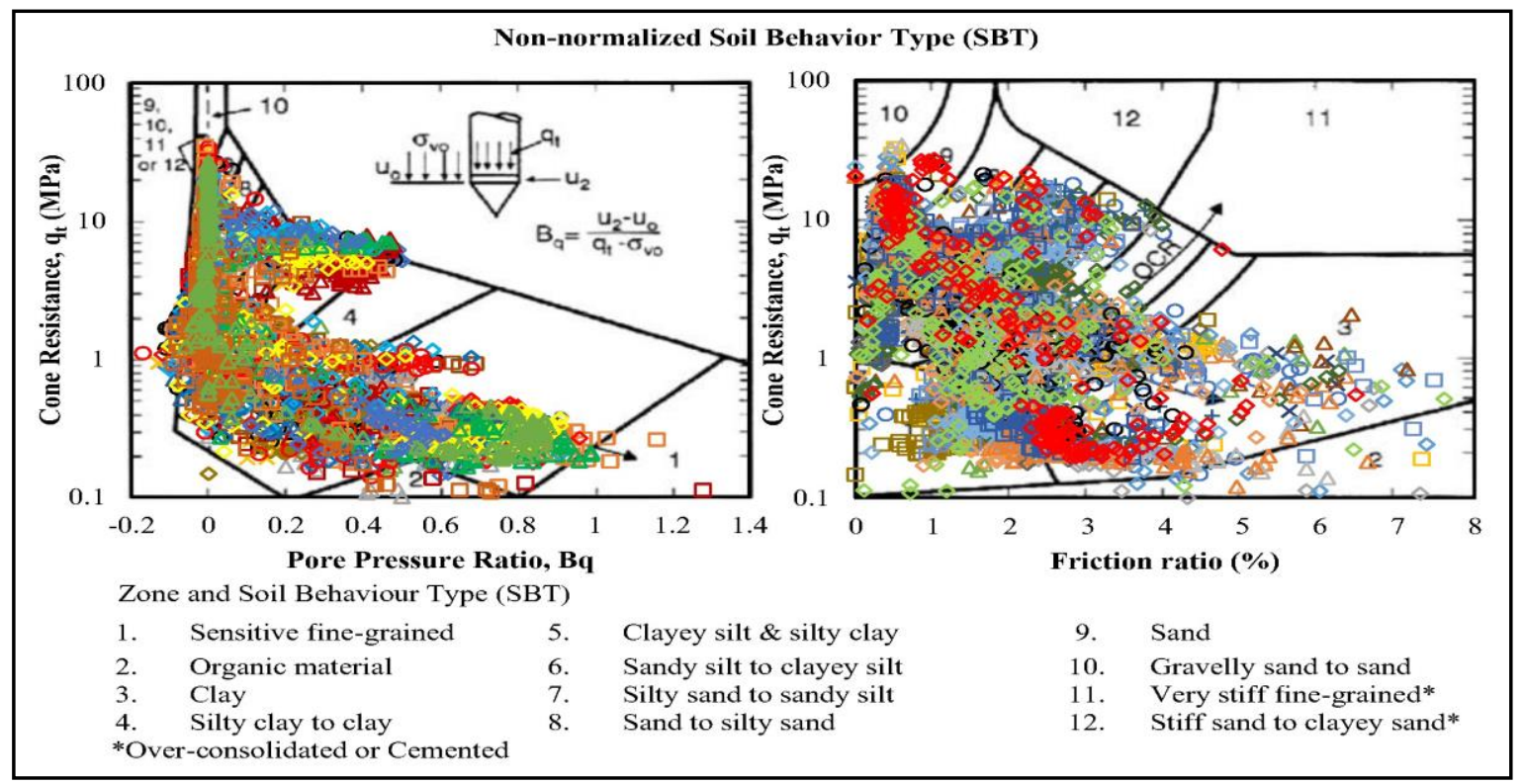

Fig. 10:- Non-normalized CPT soil behavior type (SBT) chart from Piezocone penetration data (Robertson et al., 1986).

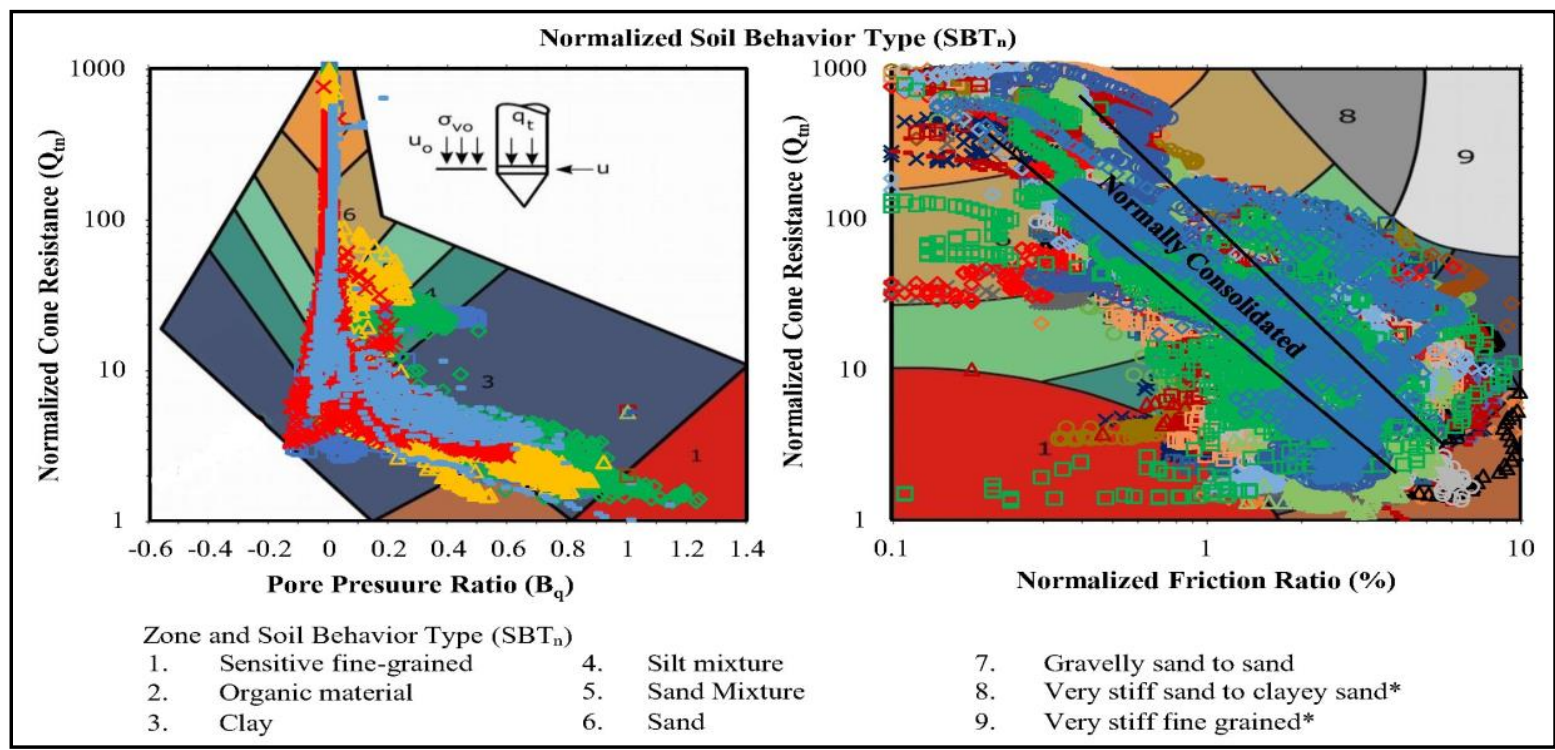

Fig. 11:- Normalized CPT soil behavior type $\left(\mathrm{SBT}_{\mathrm{n}}\right)$ chart (Robertson, 1990).

\begin{tabular}{|c|c|c|c|c|}
\hline Zone & Soil Behavior Type & Common SBT Description & Zone & Soil Behavior Type \\
\hline 1 & Sensitive fine-grained & Sensitive fine-grained & 1 & Sensitive fine-grained \\
\hline 2 & Organic material & Clay-organic soil & 2 & Organic material \\
\hline 3 & Clay & Clays-Clay to Silty Clay & 3 & Clay \\
\hline 4 & Silty Clay to Clay & \multirow{2}{*}{ Silt mixtures- Clayey Silt \& Silty Clay } & \multirow{2}{*}{4} & \multirow{2}{*}{ Silt mixture } \\
\hline 5 & Clayey silt \& Silty Clay & & & \\
\hline 6 & Sandy Silt to Clayey Silt & \multirow{2}{*}{ Sand Mixture- Silty Sand to Sandy Silt } & \multirow{2}{*}{5} & \multirow{2}{*}{ Sand Mixture } \\
\hline 7 & Silty Sand to Sandy Silt & & & \\
\hline 8 & Sand to Silty Sand & Sands-clean Sand to Silty Sands & 6 & Sand \\
\hline 9 & Sand & \multirow{2}{*}{ Dense Sand to Gravelly Sand } & \multirow{2}{*}{7} & \multirow{2}{*}{ Gravelly Sand to Sand } \\
\hline 10 & Gravelly Sand to Sand & & & \\
\hline 11 & Very stiff fine-grained* & Stiff Sand to Clayey Sand* & 8 & Very stiff Sand to Clayey Sand* \\
\hline 12 & Stiff Sand to Clayey Sand* & Stiff fine-grained* & 9 & Very stiff fine-grained* \\
\hline \multicolumn{2}{|c|}{ SBT Zone (Robertson et al., 1986) } & Common SBT & \multicolumn{2}{|c|}{$\mathrm{SBT}_{\mathrm{n}}$ Zone (Robertson, 1990) } \\
\hline
\end{tabular}

Table 6:- Comparison between non-normalized (SBT) and normalized $\left(\mathrm{SBT}_{\mathrm{n}}\right)$ soil behavior type chart from Piezocone penetration data (Robertson et al., 1986 and Robertson, 1990). 
ISSN No:-2456-2165

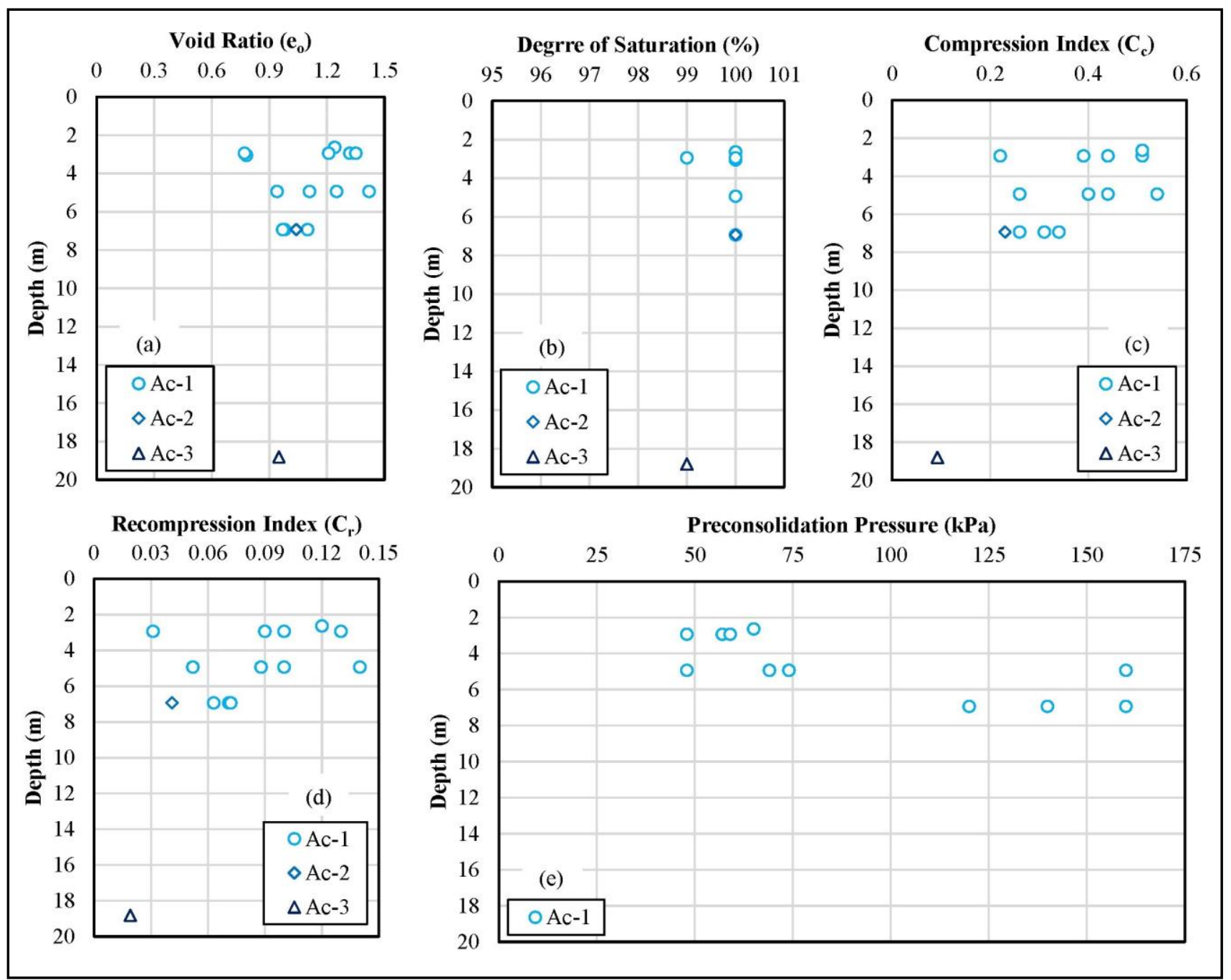

Fig. 12:- Distribution of soil consolidation properties compared with the depth of the project area. (a) Void ratio (b) Degree of saturation (c) Compression Index (d) Recompression Index and (e) Preconsolidation Pressure of Ac-1 layer.

The consolidation properties of soil are shown in Figs. 12 and 13. The project area soils are saturated with $>95 \%$ water or it can considered as fully saturated soils. The natural void ratio of cohesive soils ranges from 0.78-1.42 and average as 1.14 for Ac-1 layer. The values decrease to 1.04 for Ac-2 and at lower parts 0.95 for Ac-3. The void ratio suggests the cohesive soils are mainly composed of inorganic to organic Silt and Clay of high plasticity at upper parts but sandy soils with low to high plasticity at the lower part (Hough, 1966). This void ratio indicates the soils dominated by Clay and Silt, and the Sand content gradually increases with increased depth.

Consolidation parameters such as compression index $\left(\mathrm{C}_{\mathrm{c}}\right)$ and recompression index $\left(\mathrm{C}_{\mathrm{r}}\right)$ values for Ac-1 are respectively $0.22-0.54$ and $0.031-0.14$. The Ac-2 and Ac-3 layer shows the compression index values 0.23 and 0.092 .
The recompression or swelling index for Ac-2 and Ac-3 layer indicates respectively 0.041 and 0.019 . According to Kulhawy \& Mayne (1990), the cohesive soils (Ac-1 \& Ac-2) at shallower depth is composed of very slightly to very highly compressible clay and silt. The Ac-3 layer is slight to very slightly compressible (Kulhawy \& Mayne, 1990).

One dimensional consolidation test result indicates the soils have exerted a preconsolidation pressure. This preconsolidation pressure is very low at a shallower depth in the case of the Ac-1 layer. Approximately the P'c value ranges from 48 to $160 \mathrm{kPa}$ has an average value of $91 \mathrm{kPa}$ for Ac-1 layers (Fig. 12). It suggests the upper cohesive soil is normal to slightly over consolidated in nature, further indicating that any load placed on this soil layer may result in the primary settlement. 

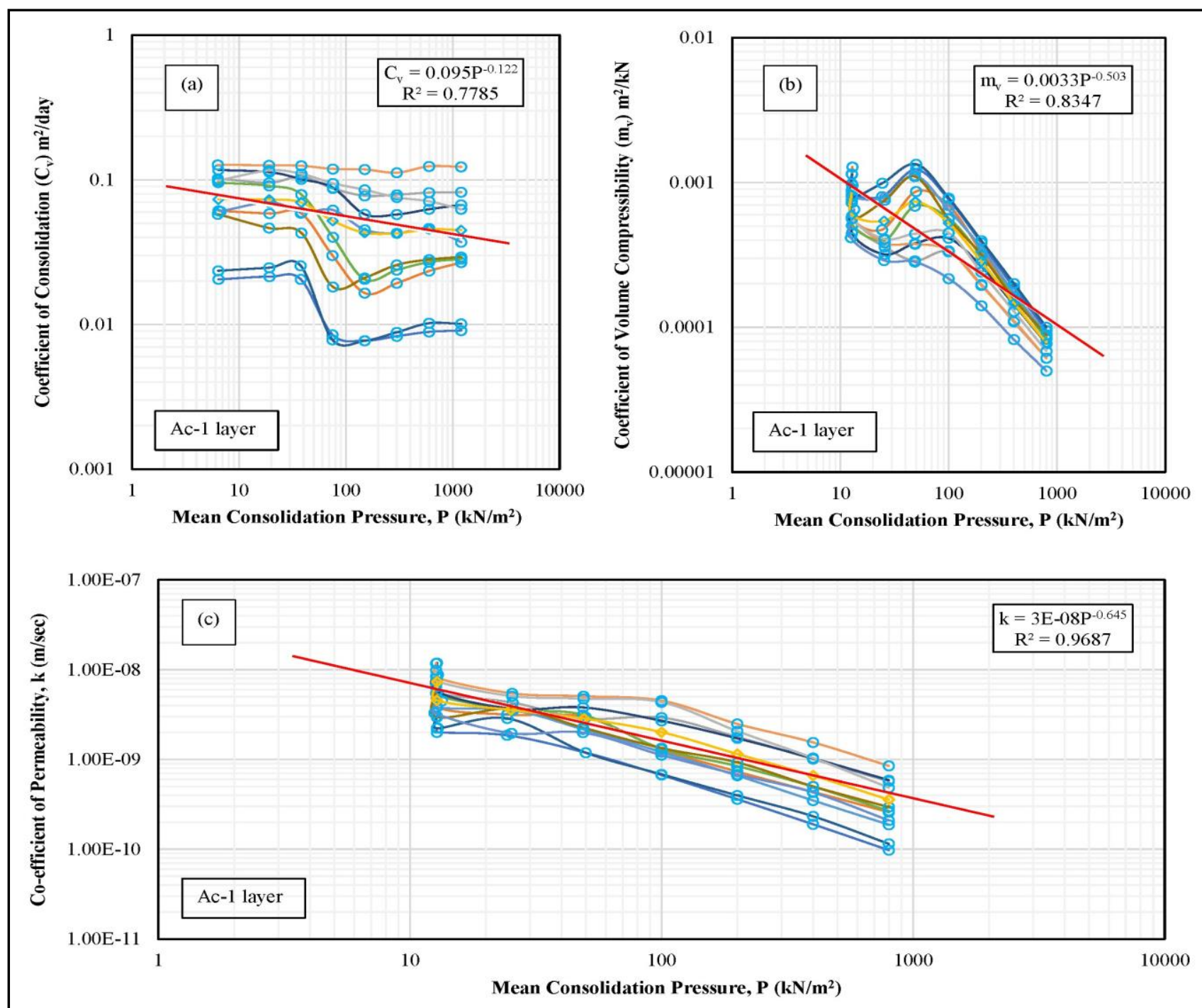

Fig. 13:- The consolidation pressure against Co-efficient of consolidation (a), co-efficient of volume compressibility (b) and coefficient of permeability (c) of Ac-1 soil layer.

From the consolidation test results, the coefficients of consolidation for the Ac-1 layer is estimated as $\mathrm{C}_{\mathrm{v}}=0.095 \mathrm{P}$ $0.122 \mathrm{~m}^{2} /$ day (Fig. 13). Whereas, the consolidation test results (Figure 13) indicated that the coefficients of volume compressibility across the expected range of the design load for the Ac-1 layer are approximate, $\mathrm{m}_{\mathrm{v}}=0.0033 \mathrm{P}^{-0.503}$ $\left(\mathrm{m}^{2} / \mathrm{kN}\right)$. These values indicate the foundation soils are unstable because of the expected settlement amount. The coefficient of permeability $\left(\mathrm{k}=3 \mathrm{E}-08 \mathrm{P}^{-0.645}\right)$ of the Ac-1 layer indicates the soils are soft Clay and Silty Clay fall within the narrow range of $10^{-08}$ to $10^{-11}$ and act as an impervious clay deposit below the zone of weathering. With decreasing clay mineral and organic content, or with increasing silt content, soft clays come to equilibrium under natural sedimentation-consolidation conditions at increasingly small void ratios (Terzaghi et al., 1996). Therefore, the consolidation of these soils is time-dependent, and it takes a long period for consolidation.

The shear strength or bearing capacity determined from the in-situ cone penetration test results (Fig. 14). From the CPT results, the undrained shear strength of the Ac-1 layer is found $<25 \mathrm{kPa}$, which is consistent with the UU triaxial test. The Ac-2, Ac-3, Ac-4 and Dc layers are respectively showing the shear strength (Table 5) around $25-50 \mathrm{kPa}, 50-125 \mathrm{kPa}$, $125-250 \mathrm{kPa}$ and $>250 \mathrm{kPa}$. According to ISRM (Brown, 1981), the cohesive soils are very soft to soft at the upper parts, firm to stiff at the middle portion, and very stiff to hard at the lower parts. 


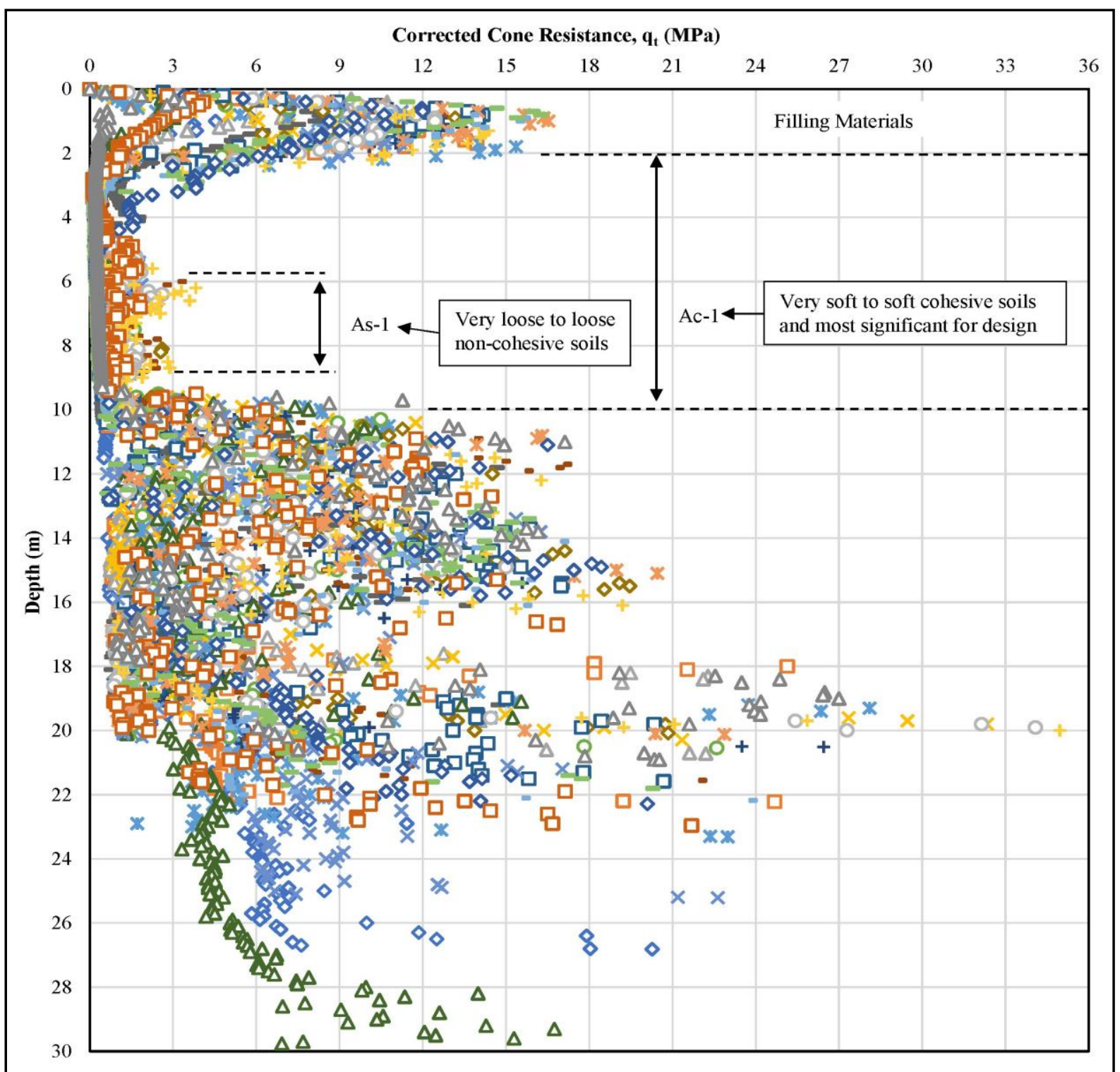

Fig. 14:- Load-bearing strength against the depth of soil from the Piezocone Penetration Test (CPT).

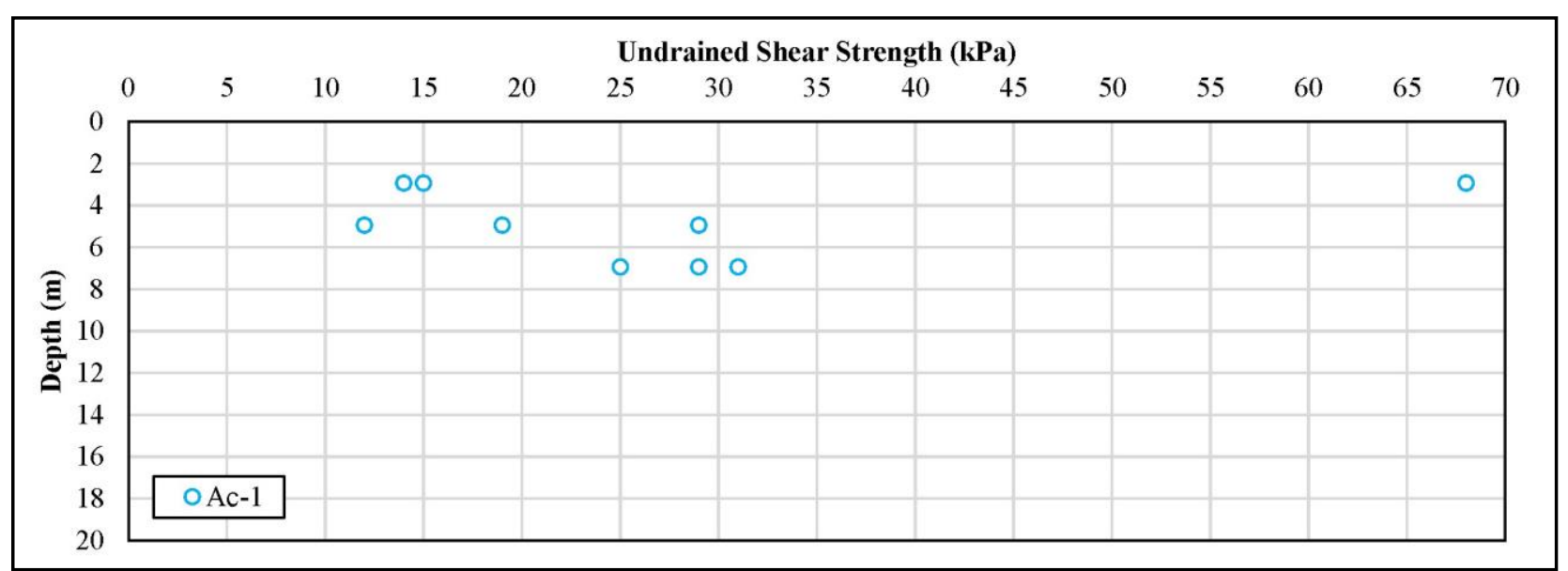

Fig. 15:- Undrained shear strength of soil layer (Ac-1) from Triaxial (UU) Test.

From the undrained shear strength tests, it establishes that the shear strength of cohesive soils ranges from 12$68 \mathrm{kPa}$ up to a depth of $10 \mathrm{~m}$ (Fig. 15). The soils within this depth indicate mainly the Ac-1 layer. The Ac-1 soil layer is soft to very soft, normally to slightly over consolidated with very high compressibility and low shear strength values. Shear strength parameters ( $c^{\prime}$ and $\left.\varphi^{\prime}\right)$ of Ac-1 and Ac-2 layers range from $6.0 \mathrm{kPa}$ to $7.0 \mathrm{kPa}$ and $29^{\circ}$ to $31^{\circ}$, and these values 
suggest the cohesive soils consists of very loose silt to finegrained Sand (Hunt, 2005). Therefore, it established that the foundation soils are unstable and collapsed because of low shear strength or less bearing capacity. The settlement of foundation soils is unavoidable because of design load and expecting a total and differential settlement during and after the construction because of high compressibility values.

\section{CONCLUSIONS}

Assessment based on the soil characteristics established the research area consists of two types of soils, i.e., Cohesive Clayey and non-cohesive Sandy soils. The cohesive clayey soils are predominantly composed of dark gray to gray CLAY, CLAY with Sand, SILT with Sand, and Sandy CLAY with fine to medium-grained sand with the presence of organic matter, trace of mica and seashell fragments. The upper cohesive soil layer (Ac-1) is very soft to soft, normal to slightly consolidated with a low undrained cohesion 6.0$7.0 \mathrm{kPa}$. The soil layer thickness is around $2.4-10.2 \mathrm{~m}$ and expected to have a high potential for differential settlement because of a proposed design load. The construction of an engineering structure on this ground considered a potential risk because of these soft cohesive clay soils. The lower cohesive soils (Ac-2 and Ac-3) are firm to very stiff, over consolidated with a thickness of 1.0 to $7.6 \mathrm{~m}$ and 1.0 to 5.0 $\mathrm{m}$, and show moderate to high shear and compressive strengths with low compressibility relating to the expected range of the design load. The non-cohesive soils composed of gray to dark gray (and occasionally encounter dark brown and brownish-gray) SAND, SAND with Silt, Silty SAND, Clayey SAND and Gravelly SAND. Sand is predominantly fine-grained and laminated with clay and silt layers. The upper layer (As-1) is loose to very loose with the range of SPT N-values from 0.0 to 10 . The cone resistance is generally $3 \mathrm{MPa}$ or less for this layer. The lower sandy soil (As-2 and As-3) layers are identified as poorly graded Clayey or Silty SAND. The SPT results revealed the lower sandy soils as medium dense to dense that shows small or less immediate settlement when a load placed on these soils. Geotechnical site conditions are challenging and deplorable, and the upper soft clay (Ac-1) layer complicates the design and construction of the engineering structures. Especially in terms of foundation soil instability and settlement for certain structure types.

To mitigate these challenges or to avoid design difficulties, it is indispensable to increase the strengths of soft ground. Ground improvement techniques help to increase the density, shear strength and consolidation of soils. The prefabricated vertical drain (PVD) with or without a surcharge load can be applied for ground improvement by accelerating the consolidation process and speeding up the drainage capacity of subsoils. The deep mixing method (DMM) can be applied to mitigate these challenges quickly by increasing the shear strength of the soft ground of the researched area. The research findings can be used as a general guideline for ground improvement and land development planning of the project area and also for power plant design facilitation. These works help to understand the actual ground condition and provide authentic real field information for future development projects near this coastal area. Also, it is significant for sustainable development and mitigation planning of the study area.

\section{ACKNOWLEDGEMENTS}

The authors would like to acknowledge the Coal Power Generation Company Bangladesh Limited (CPGCBL) and Matarbari joint Venture Consultant (MJVC). Thanks to Sumitomo Corporation and the sub-contractor, especially Penta-Ocean Construction Company Ltd (POC) for providing the necessary data about soil investigation works. Thanks also due to power plant and port team colleague for helping and advising to carry out this research work.

\section{REFERENCES}

[1]. Alam, M. K., Hasan, A. K. M. S., Khan, M. R., \&Whitney, J. W. (1990). Geological Map of Bangladesh.

[2]. ASTM D 1586 (2011). Standard Test Method for Standard Penetration Test (SPT) and Split-Barrel Sampling of Soils. ASTM Standard Test Method. https://doi.org/10.1520/D1586-11.2

[3]. ASTM D 1587 (2008). Standard Practice for ThinWalled Tube Sampling of Soils for Geotechnical Purposes. ASTM Standard Practice. https://doi.org/10.1520/D1587-08R12E1.1.4.1

[4]. ASTM D 2216 (2010). Standard Test Methods for Laboratory Determination of Water (Moisture) Content of Soil and Rock by Mass. ASTM International. https://doi.org/10.1520/D2216-10.N

[5]. ASTM D 2435/M 2435 (2011). Standard Test Methods for One-Dimensional Consolidation Properties of Soils Using Incremental Loading. In Annual Book of ASTM Standards [4.08].

[6]. ASTM D 2487 (2017). Standard Practice for Classification of Soils for Engineering Purposes (Unified Soil Classification System). A. https://doi.org/10.1520/D2487-11.

[7]. ASTM D 2850 (2015). Standard Test Method for Unconsolidated-Undrained Triaxial Compression Test on Cohesive Soils. ASTM International. https://doi.org/10.1520/D2850-15.2

[8]. ASTM D 422 (2007). Standard Test Method for Particle-Size Analysis of Soils. ASTM International. https://doi.org/10.1520/D0422-63R07E01.2

[9]. ASTM D 4318 (2001). Method of Test for Liquid Limit, Plastic Limit, and Plasticity Index of Soils. Test Method Ls-703/704. https://doi.org/10.1520/D4318-05

[10]. ASTM D 6519 (2015). Standard Practice for Sampling of Soil Using the Hydraulically Operated Stationary Piston Sampler 1. ASTM International. https://doi.org/10.1520/D6519-08.

[11]. ASTM D 7263 (2009). Standard Test Methods for Laboratory Determination of Density (Unit Weight) of Soil Specimens. ASTM International. https://doi.org/10.1520/D7263-09.2

[12]. ASTM D 854 (2002). Standard Test Methods for Specific Gravity of Soil Solids by Water Pycnometer. ASTM International. 
[13]. ASTM D5778 (2012). Standard Test Method for Performing Electronic Friction Cone and Piezocone Penetration Testing of Soils 1. ASTM International. https://doi.org/10.1520/D5778-12

[14]. Brown, E. T. (1981). Rock characterization, testing and monitoring. ISRM suggested methods: Oxford: Pergamon Press, 1981, 211P. International Journal of Rock Mechanics and Mining Sciences \& Geomechanics Abstracts.

[15]. Hough, B. K. (1966). Basic soils engineering. Soil Mechanics and Foundation Engineering. https://doi.org/10.1007/BF01703491

[16]. Hunt, R. E. (2005). Geotechnical Engineering Investigation Handbook. In Geotechnical Engineering Investigation Handbook. https://doi.org/10.1201/9781420039153

[17]. Kulhawy, F. H., \& Mayne, P. W. (1990). Manual on Estimating Soil Properties for Foundation Design. Ostigov. https://doi.org/EPRI-EL-6800

[18]. Robertson, P. K. (1990). Soil classification using the cone penetration test. Canadian Geotechnical Journal. https://doi.org/10.1139/t90-014

[19]. Robertson, P. K. (2010). Evaluation of flow liquefaction and liquefied strength using the cone penetration test. Journal of Geotechnical and Geoenvironmental Engineering. https://doi.org/10.1061/(ASCE)GT.1943-5606.0000286

[20]. Robertson, P. K., Campanella, R. G., Gillespie, D., \& Greig, J. (1986). USE OF PIEZOMETER CONE DATA.

[21]. Terzaghi, K., Peck, R. B., \& Mesri, G. (1996). Soil mechanics in engineering practice (3rd Edition). https://doi.org/10.1016/s0013-7952(97)81919-9. 